\title{
TOX High Mobility Group Box Family Member 3
}

National Cancer Institute

\section{Source}

National Cancer Institute. TOX High Mobility Group Box Family Member 3. NCI

Thesaurus. Code C68712.

TOX high mobility group box family member 3 protein ( $576 \mathrm{aa}, \sim 63 \mathrm{kDa}$ ) is encoded by the human TOX3 gene. This protein may be a transcription factor. 